\title{
Heavy Metals Level in Clarias gariepinus (Catfish), Oreochromis niloticus (Tilapia) and Chrysichthys nigroditatus (Bagrid catfish) collected from Ogun River, Ogun State, Nigeria
}

\author{
${ }^{1}$ NWUDE, DO; ${ }^{2 *}$ BABAYEMI, JO; ${ }^{1}$ AJIBODE, CP \\ ${ }^{I}$ Department of Chemical Sciences, Bells University of Technology, Ota, Nigeria \\ ${ }^{2}$ Department of Chemical Sciences, Anchor University Lagos, Nigeria \\ *Corresponding Author Email: babayemola@yahoo.co.uk
}

\begin{abstract}
Aquatic organisms such as fish are prone to contamination by water pollutants such as heavy metals. This study aims at assessing the levels of heavy metals in the fillet tissues of 75 fish samples comprising Clarias gariepinus (Catfish), Oreochromis niloticus (Tilapia) and Chrysichthys nigroditatus (Bagrid catfish) from five (5) different fishing locations along the Ogun River, Ogun State. The fillet tissues of the fish samples were digested and analysed for $\mathrm{Zn}, \mathrm{Pb}, \mathrm{Fe}, \mathrm{Cr}$ and $\mathrm{Cd}$ using a Perkin Elmer, AAnalyst - 200 Atomic Absorption Spectrometer. The concentration of $\mathrm{Zn}$ in Clarias gariepinus, Oreochromis niloticus and Chrysichthys nigroditatus were $5.37 \pm 2.558,6.58 \pm 2.35$ and $5.11 \pm 1.55$ respectively; while the levels of $\mathrm{Pb}$ in the species were Clarias gariepinus (1.30 \pm 3.099$)$, Oreochromis niloticus (1.01 \pm 0.95$)$ and Chrysichthys nigroditatus $(0.35 \pm 0.59)$. Concentrations of $\mathrm{Fe}, \mathrm{Cr}$ and $\mathrm{Cd}$ in the species were Clarias gariepinus (8.87 $\pm 3.547,0.08 \pm 0.098$ and $0.09 \pm 0.100$ ), Oreochromis niloticus $(8.96 \pm 2.21,0.12 \pm 0.11$ and $0.11 \pm 0.11)$ and Chrysichthys nigroditatus $(8.16 \pm 3.88,0.11 \pm 0.11$ and $0.11 \pm 0.11$ ). The data revealed that most of these values were lower than $\mathrm{FAO} / \mathrm{WHO}$ permissible except $\mathrm{Pb}$ and $\mathrm{Cr}$. Some of the fish sampled may pose health hazards to the consumers. There is a need for constant monitoring of pollutants in Ogun River.
\end{abstract}

DOI: $\underline{\text { https://dx.doi.org/10.4314/jasem.v24i8.19 }}$

Copyright: Copyright $\left({ }^{\circ} 2020\right.$ Nwude et al. This is an open access article distributed under the Creative Commons Attribution License (CCL), which permits unrestricted use, distribution, and reproduction in any medium, provided the original work is properly cited.

Dates: Received: 30 May 2020; Revised: 03 July 2020; Accepted: 05 August 2020

Keywords: Heavy metals, Clarias gariepinus, Oreochromis niloticus, Chrysichthys nigroditatus, Ogun River

The modern societies are faced with serious concerns about some global environmental challenges; developing countries in particular currently experience growing and complex pollution problems. The global environmental pollution, water pollution and waste management in particular, have attracted international public health attention. From the perspective of chemicals or hazardous substances, river water samples, sediments and some species of fish in Nigeria have been investigated (Unyimadu et al., 2019; 2018a,b,c; 2017). As an indicator of general environmental pollution and as a route of human exposure, animals like cattle have been investigated (Nwude et al., 2012; 2011a,b; 2010a,b,c). Fish is often used as a biomarker of quality of water bodies since the quality of the fish depends on the quality of the water (Fakankun et al., 2012; Olusola and Festus, 2015; Obot et al., 2016; Bawuro et al., 2018). Organic and inorganic chemical species often constitute the main water pollutants and their levels are some of the measures to determine the water quality. Apart from the implications for human health (Kayode et al., 2011), the presence and/or the levels of inorganic and organic substances in water bodies pose threats to the health of aquatic organisms including fish (Jacquin et al., 2020; Adewuyi et al., 2010; Austin, 1999). Anthropogenic activities are major sources of heavy metals pollution of rivers (Babayemi et al., 2016). Agricultural activities, runoffs from industrial areas, sewage effluents from industrial activities (Zhou et al., 2020) and mining activities (Gabrielyan et al., 2018) contribute to the levels of heavy metals in the water bodies. Furthermore, inappropriate waste management or disposal is the main source of heavy metals pollution (Babayemi et al., 2017a). Ogun State has a larger number of industries in Nigeria and the discharge of wastewater from these industries may have an impact on the chemical characteristics of Ogun River, which is the main river in Ogun State, and hence on the quality of fish in this river. Apart from the fact that fish may be used as an indicator of chemical contaminants in rivers, its safety for consumption as being sourced from major rivers in Nigeria should be assessed. It is a widely consumed aquatic product sourced from major rivers in Nigeria (Unyimadu et al., 2017; 2018a, b). Therefore, the consumption of fish of various species may be a significant contributor to the consumers' intake of 
some contaminants. Among other species, Clarias gariepinus (Catfish), Oreochromis niloticus (Tilapia) and Chrysichthys nigroditatus (Bagrid catfish) are very common in Ogun River (Iji and Adeogun, 2014); and also, some consumers have a preference for these (Unyimadu et al., 2018a,b). Investigating these fish species for the levels of heavy metals is therefore necessary. Common heavy metals assessed in previous studies to assess environmental pollution status in some parts of Nigeria include $\mathrm{Pb}, \mathrm{Cd}, \mathrm{Cr}, \mathrm{Fe}$ and $\mathrm{Zn}$ (Azeez and Babayemi, 2020; Bawuro et al., 2018; Gabrielyan et al., 2018; Babayemi et al., 2017b). Though previous studies have carried out some assessments to determine the levels of heavy metals in fish, water or sediments from some surface waters in Nigeria (Ibrahim et al., 2018; Obot et al., 2016), and other locations along Ogun River: Opeji (Adeosun et al., 2015), Oke-Odan (Makanjuola and Makanjuola, 2018), Abeokuta (Olatunde et al., 2014; Ayanda et al., 2019) and Ketu (Adeniyi et al., 2008), spatial and seasonal changes in the physical and chemical properties of water, and consequently the health or quality of fish, call for continual monitoring of every other location along this river for levels of heavy metals. Therefore, the objective of this research was to evaluate and report the levels of $\mathrm{Zn}, \mathrm{Pb}, \mathrm{Fe}, \mathrm{Cr}$ and $\mathrm{Cd}$ in Clarias gariepinus (Catfish), Oreochromis niloticus (Tilapia) and Chrysichthys nigroditatus (Bagrid catfish) collected from Ogun River in Ogun State, Nigeria.

\section{MATERIALS AND METHODS}

Sample Collection: A total of 75 (5 samples of each) fish samples of three different fish species were purchased in May 2019 from five different fishing points along Ogun River. The coordinates of the sampling locations are shown in Table 1. All samples were packaged using an aluminium foil on ice, properly labeled and transported to the laboratory freezer for proper storage, awaiting analysis. The fish samples were: Clarias gariepinus (Catfish), Oreochromis niloticus (Tilapia) and Chrysichthys nigroditatus (Bagrid catfish).

Table 1: GPS locations and names of sampled sites

\begin{tabular}{lllll}
\hline Oyan Dam & Oriyanrin & Adigbe Bridge & Apo Village & Odo-Eran Lafenwa \\
\hline N6 $6^{\circ} 39^{\prime} 38.5452^{\prime \prime}$ & $\mathrm{N} 6^{\circ} 40^{\prime} 14.502^{\prime \prime}$ & $\mathrm{N}^{\circ} 41^{\prime} 7.6164^{\prime \prime}$ & $\mathrm{N}^{\circ} 41^{\prime} 5.4704^{\prime \prime}$ & $\mathrm{N6}^{\circ} 40^{\prime} 51.654^{\prime \prime}$ \\
$\mathrm{E}^{0} 5^{\prime} 23.082^{\prime \prime}$ & $\mathrm{E}^{\prime \prime} 6^{\prime} 44.2224^{\prime \prime}$ & $\mathrm{E} 3^{0} 10^{\prime} 12.9792^{\prime \prime}$ & $\mathrm{E}^{0} 10^{\prime} 42.3588^{\prime \prime}$ & $\mathrm{E}^{0} 12^{\prime} 1.53^{\prime \prime}$ \\
\hline
\end{tabular}

Sample Digestion: All glassware used was soaked in water and soap for two hours, rinsed with distilled water and then with a mixture consisting of $520 \mathrm{~mL}$ de-ionized water, $200 \mathrm{~mL}$ concentrated $\mathrm{HCl}$ and 80 $\mathrm{mL} \mathrm{H}_{2} \mathrm{O}_{2}$. They were rinsed with de-ionized water and then oven-dried, away from dust and contamination. The bench was cleaned with soap and water and rinsed with acetone. Foil paper was spread on the bench. The frozen fish samples were placed on top and allowed to defrost. The fish samples were filleted, and the fillets were digested using the wet digestion method. The analytical procedure followed that of Muinde et al. (2013) with some modifications. Five grams $(5 \mathrm{~g})$ of each of the individual fish samples were weighed using electronic weighing balance into a $50 \mathrm{~mL}$ Pyrex beaker for digestion using $10 \mathrm{~mL}$ mixture of concentrated $\mathrm{HCl}$ and $\mathrm{HNO}_{3}$, in the ratio of 3:1 (Aqua regia) for $3 \mathrm{~h}$ at $60^{\circ} \mathrm{C}$ using a hot plate inside the fume chamber.

After digestion, the content of the flask was filtered into a $50 \mathrm{~mL}$ standard flask and made up to the mark with deionized water and then transferred into the laboratory sample bottles and kept at room temperature until analysis. Sample blanks were prepared by taking $10 \mathrm{~mL}$ of the reagents mixture through the same procedure.
Analysis of heavy metals: Aliquots of the filtrates were analysed for $\mathrm{Zn}, \mathrm{Pb}, \mathrm{Cr}, \mathrm{Cd}$ and $\mathrm{Fe}$ using Atomic Absorption Spectrophotometer (AAS) (modelPerkins Elmer AAnalyst-200). The calibration of the instrument was carried out using standard solutions. The standard analytical conditions are shown in Table 2. The data were analysed using SPSS.

Table 2: Standard Analytical Condition for Perkin Elmer, AAnalyst-200 AAS

\begin{tabular}{llll}
\hline Element & $\begin{array}{l}\text { Wavelength } \\
(\mathrm{nm})\end{array}$ & $\begin{array}{l}\text { Lamp Current } \\
(\mathrm{mA})\end{array}$ & $\begin{array}{l}\text { Slit Width } \\
(\mathrm{nm})\end{array}$ \\
\hline $\mathrm{Pb}$ & 217.0 & 5 & 1.0 \\
$\mathrm{Cd}$ & 228.8 & 3 & 0.5 \\
$\mathrm{Cr}$ & 359.3 & 6 & 0.2 \\
$\mathrm{Fe}$ & 248.3 & 7 & 0.2 \\
\hline
\end{tabular}

\section{RESULTS AND DISCUSSION}

The detailed results are presented in Table 3 . Generally, the concentrations of the heavy metals were $\mathrm{Zn}(2.34-8.85 \mathrm{mg} / \mathrm{kg}), \mathrm{Pb}(\mathrm{ND}-4.18 \mathrm{mg} / \mathrm{kg}), \mathrm{Fe}$ $(5.76-11.60 \mathrm{mg} / \mathrm{kg}), \mathrm{Cr}(0.03-0.28 \mathrm{mg} / \mathrm{kg})$ and $\mathrm{Cd}$ $(0.03-0.28 \mathrm{mg} / \mathrm{kg})$.

Heavy metal concentrations based on locations: Table 4 shows the heavy metals concentration in tissues of fish collected from five (5) different locations in Ogun River. $\mathrm{Zn}$ concentration was highest in tissues of fish collected from Odo-Eran Lafenwa and lowest at Oyan Dam with mean values of $7.77 \mathrm{mg} / \mathrm{kg}$ and $4.60 \mathrm{mg} / \mathrm{kg}$ 
respectively; and with the overall mean of $5.69 \mathrm{mg} / \mathrm{kg}$ for the Ogun River. There is a significant difference $(\mathrm{P}$ $<0.05)$ in the levels of $\mathrm{Zn}$ in the fish samples obtained from the five different locations. The $\mathrm{Pb}$ concentration was highest in Oriyanrin and least in Odo-Eran Lafenwa with mean values of $1.67 \mathrm{mg} / \mathrm{kg}$ and $0.57 \mathrm{mg} / \mathrm{kg}$ respectively. Generally fishes collected from Ogun River have a $\mathrm{Pb}$ concentration of 0.88 $\mathrm{mg} / \mathrm{kg}$. No significant difference $(\mathrm{P}>0.05)$ was observed in the levels of $\mathrm{Pb}$ in the samples from the five (5) different locations. The highest $\mathrm{Fe}$ concentration was obtained in fish samples from Oriyanrin $(10.39 \mathrm{mg} / \mathrm{kg})$ and the least was obtained from fish fillet tissues from Oyan Dam $(7.81 \mathrm{mg} / \mathrm{kg})$ with a mean of $8.66 \mathrm{mg} / \mathrm{kg}$ for all the five locations. There is no significant difference $(\mathrm{P}>0.05)$ in the levels of $\mathrm{Fe}$ in the fish samples from all the locations. For $\mathrm{Cr}$, samples of fish obtained from Apo Village had the highest $\mathrm{Cr}$ concentration while those obtained from Odo-Eran Lafenwa had the least, having a mean of $0.10 \mathrm{mg} / \mathrm{kg}$ for all the samples. There is a significant difference $(\mathrm{P}<0.05)$ in the levels of $\mathrm{Cr}$ for all the locations. Cd concentration was highest in fish tissues obtained from Apo Village $(0.17 \mathrm{mg} / \mathrm{kg})$ and least in the one from Oriyanrin $(0.07 \mathrm{mg} / \mathrm{kg})$, with a mean of $0.10 \mathrm{mg} / \mathrm{kg}$. There is a significant difference $(\mathrm{P}<0.05)$ in the concentrations of $\mathrm{Cd}$ in the samples.

Table 3: Mean values of heavy metals concentration $(\mathrm{mg} / \mathrm{kg})$ in fish from different locations along Ogun River

\begin{tabular}{lllllll}
\hline Fish species & Location & $\mathrm{Zn}$ & $\mathrm{Pb}$ & $\mathrm{Fe}$ & $\mathrm{Cr}$ & $\mathrm{Cd}$ \\
\hline $\begin{array}{l}\text { Clarias } \\
\text { gariepinus }\end{array}$ & Oyan Dam & $2.34 \pm 1.64$ & $\mathrm{ND}$ & $5.76 \pm 3.71$ & $0.21 \pm 0.14$ & $0.21 \pm 0.14$ \\
& & & & & \\
& Oriyanrin & $6.01 \pm 1.29$ & $4.18 \pm 6.45$ & $9.12 \pm 2.08$ & $0.06 \pm 0.08$ & $0.08 \pm 0.09$ \\
& Adigbe Bridge & $4.34 \pm 1.39$ & $0.45 \pm 0.53$ & $7.57 \pm 0.60$ & $0.05 \pm 0.04$ & $0.07 \pm 0.06$ \\
& Apo Village & $5.29 \pm 1.26$ & $1.23 \pm 1.03$ & $11.60 \pm 4.62$ & $0.05 \pm 0.05$ & $0.05 \pm 0.05$ \\
& Odo-Eran Lafenwa & $8.85 \pm 1.71$ & $0.83 \pm 0.51$ & $10.28 \pm 3.10$ & $0.03 \pm 0.20$ & $0.03 \pm 0.02$ \\
Oreochromis & & & & & & \\
niloticus & & & & & \\
& Oyan Dam & $7.42 \pm 2.76$ & $2.18 \pm 0.71$ & $9.11 \pm 0.72$ & $0.05 \pm 0.01$ & $0.05 \pm 0.01$ \\
& Oriyanrin & $3.99 \pm 0.69$ & $0.13 \pm 0.49$ & $10.86 \pm 2.29$ & $0.05 \pm 0.05$ & $0.03 \pm 0.05$ \\
& Adigbe Bridge & $6.03 \pm 2.68$ & $1.24 \pm 0.91$ & $10.24 \pm 1.75$ & $0.14 \pm 0.13$ & $0.12 \pm 0.14$ \\
& Apo Village & $6.85 \pm 1.21$ & $1.10 \pm 0.69$ & $5.94 \pm 1.35$ & $0.28 \pm 0.04$ & $0.28 \pm 0.04$ \\
& Odo-Eran Lafenwa & $8.59 \pm 1.31$ & $0.42 \pm 0.15$ & $8.66 \pm 0.63$ & $0.06 \pm 0.06$ & $0.06 \pm 0.63$ \\
Chrysichthys & & & & & & \\
nigroditatus & & & & & \\
& Oyan Dam & $4.03 \pm 0.88$ & $\mathrm{ND}$ & $8.54 \pm 1.69$ & $0.04 \pm 0.06$ & $0.04 \pm 0.06$ \\
& Oriyanrin & $5.28 \pm 0.65$ & $0.70 \pm 1.03$ & $11.19 \pm 7.59$ & $0.12 \pm .081$ & $0.11 \pm 0.08$ \\
& Adigbe Bridge & $3.82 \pm 1.41$ & $0.53 \pm 0.57$ & $7.04 \pm 1.37$ & $0.12 \pm 0.09$ & $0.12 \pm 0.09$ \\
& Apo Village & $6.55 \pm 1.27$ & $0.08 \pm 0.13$ & $6.38 \pm 3.15$ & $0.20 \pm 0.20$ & $0.20 \pm 0.19$ \\
& Odo-Eran Lafenwa & $5.88 \pm 1.62$ & $0.46 \pm 0.17$ & $7.67 \pm 0.59$ & $0.06 \pm 0.01$ & $0.06 \pm 0.01$ \\
\hline
\end{tabular}

Table 4: Mean Values of Heavy Metals Concentration $(\mathrm{mg} / \mathrm{kg})$ in fish based on the sample locations

\begin{tabular}{llllll}
\hline Location & $\mathrm{Zn}$ & $\mathrm{Pb}$ & $\mathrm{Fe}$ & $\mathrm{Cr}$ & $\mathrm{Cd}$ \\
\hline Oyan Dam & $4.60 \pm 2.82$ & $0.64 \pm 1.24$ & $7.81 \pm 2.68$ & $0.10 \pm 0.16$ & $0.10 \pm 0.12$ \\
Oriyanrin & $5.09 \pm 1.22$ & $1.67 \pm 3.96$ & $10.39 \pm 4.49$ & $0.08 \pm 0.07$ & $0.07 \pm 0.08$ \\
Adigbe Bridge & $4.73 \pm 2.03$ & $0.74 \pm 0.74$ & $8.28 \pm 1.90$ & $0.10 \pm 0.10$ & $0.10 \pm 0.96$ \\
Apo Village & $6.23 \pm 1.35$ & $0.81 \pm 0.85$ & $7.97 \pm 4.07$ & $0.17 \pm 0.15$ & $0.17 \pm 0.15$ \\
Odo-Eran Lafenwa & $7.77 \pm 2.00$ & $0.57 \pm 0.35$ & $8.87 \pm 2.05$ & $0.05 \pm 0.04$ & $0.09 \pm 0.04$ \\
Mean & $5.69 \pm 2.26$ & $0.88 \pm 1.92$ & $8.66 \pm 3.27$ & $0.10 \pm 0.11$ & $0.10 \pm 0.11$ \\
\hline
\end{tabular}

Heavy metals concentrations ( $\mathrm{mg} / \mathrm{kg}$ ) based on fish species: Based on fish species (Table 5), all the metals (except $\mathrm{Pb}$ ) were generally highest in Oreochromis niloticus; that is, this species accumulated more heavy metals than the others.

Table 5: Mean concentrations $(\mathrm{mg} / \mathrm{kg})$ of heavy metals based on the species of fish from Ogun River

\begin{tabular}{llll}
\hline Heavy & $\begin{array}{l}\text { Clarias } \\
\text { Metals }\end{array}$ & $\begin{array}{l}\text { Oreochromis } \\
\text { giloticus }\end{array}$ & $\begin{array}{l}\text { Chrysichthys } \\
\text { nigroditatus }\end{array}$ \\
\hline $\mathrm{Zn}$ & $5.37 \pm 2.558$ & $6.58 \pm 2.35$ & $5.11 \pm 1.55$ \\
$\mathrm{~Pb}$ & $1.30 \pm 3.099$ & $1.01 \pm 0.95$ & $0.35 \pm 0.59$ \\
$\mathrm{Fe}$ & $8.87 \pm 3.547$ & $8.96 \pm 2.21$ & $8.16 \pm 3.88$ \\
$\mathrm{Cr}$ & $0.08 \pm 0.098$ & $0.12 \pm 0.11$ & $0.11 \pm 0.11$ \\
$\mathrm{Cd}$ & $0.09 \pm 0.100$ & $0.11 \pm 0.11$ & $0.11 \pm 0.11$ \\
\hline
\end{tabular}

However, except in the levels of $\mathrm{Zn}$, there is no significant difference $(\mathrm{P}>0.05)$ in the levels of the metals in the different fish species. The hierarchy of the metal concentrations detected in the fish samples was $\mathrm{Fe}>\mathrm{Zn}>\mathrm{Pb}>\mathrm{Cr}>\mathrm{Cd}$. Fe and $\mathrm{Zn}$ accounted for over $90 \%$ of all the metals studied. A similar observation was reported by Koleleni and Haji (2014), Bat et al. (2017) and Salam et al. (2019). The levels of concentration of these metals were comparable to those reported for the fillet of these fish species by Fakankun et al. (2012). For Ikorodu lagoon in Lagos, they reported $0.735-1.585 \mathrm{mg} / \mathrm{kg}, \mathrm{Zn} ; \mathrm{ND}-0.392$ $\mathrm{mg} / \mathrm{kg}, \mathrm{Pb} ; 19.572-125.217 \mathrm{mg} / \mathrm{kg}$, Fe; and ND-0.947 $\mathrm{mg} / \mathrm{kg}, \mathrm{Cd}$. The observed slightly higher levels in this 
study may mean that Ogun River is more polluted than Ikorodu lagoon. It is expected that Ogun River would have more point sources of pollution than Ikorodu lagoon, as there would have been a wider dispersion of pollutants in the latter. Further compared with other studies, the mean values obtained for $\mathrm{Pb}$ and $\mathrm{Fe}$ concentration were slightly higher than those reported by Usero et al. (2003), Karadede et al. (2004), Andreji et al. (2005) and Ayeloja et al., (2014) but lower than that reported by Mbeh et al. (2019). The concentration of $\mathrm{Cd}$ was comparable with that reported by Ayeloja et al., (2014) but slightly higher than that reported by Morhit et al., (2013). The levels of $\mathrm{Zn}$ were similar to the results obtained by Usero et al., (2003) (they studied Anguilla anguilla and Solea vulgaris ) for the South Atlantic coast of Spain, higher than the values reported by Ayeloja et al. (2014) and slightly lower than the values reported by Mbeh et al. (2019). The European Commission Regulation (EC, 2006) indicates maximum levels of $0.30 \mathrm{mg} / \mathrm{kg}$ for $\mathrm{Pb}$ and $0.05 \mathrm{mg} / \mathrm{kg}$ wet wt. for Cd; and FAO (2003) maximum levels are 0.02 and 0.05 . The levels in this study generally exceeded these values, indicating that the consumption of fish from the studied locations at the time of the study may pose potential health risks to the consumers. It also suggests the need for constant monitoring of Ogun River for pollution. Some heavy metals at certain doses are essential elements for human development. $\mathrm{Zn}$ and $\mathrm{Fe}$ are essential elements. $\mathrm{Zn}$ is involved in the nucleic acid synthesis, the immune system, and neurotransmission (MacDonald, 2000). However, at higher concentrations, it can be toxic to fish (Li et al., 2019), and can be a modifier of the carcinogenic response (Bostanci et al., 2016). In humans, acute $\mathrm{Zn}$ poisoning may result in nausea, vomiting, diarrhea and fever (Agnew and Slesinger, 2020). Fe is a very common component of effluents of many industries, and such effluents are often discharged into the rivers. The toxicity of Fe to aquatic organisms may depend on the oxidation state. For example, $\mathrm{Fe}^{2+}$ is reported to be more toxic to fish than $\mathrm{Fe}^{3+}$ (Rostern, 2017). As an essential element, $\mathrm{Cr}$ is required in the human body for the metabolism of carbohydrates (National Institutes of Health, 2020). However, hexavalent $\mathrm{Cr}\left(\mathrm{Cr}^{6+}\right)$ has powerful oxidative potential and ability to cross cell membranes (Nigam et al., 2014) and is therefore considered to be toxic. Toxic heavy metals can be carcinogenic and mutagenic. And their toxicological mode of action can be the inhibition of some enzymatic systems involved in cellular energy production (Jan, 2015). Other toxic metals include $\mathrm{Cd}$ and $\mathrm{Pb}$. Lead is categorised as a priority hazardous substance. It affects the central and peripheral nervous systems, causes brain damage, cardiovascular disease, adverse effects on the developmental stages of the foetus (WHO, 2019;
Mason et al., 2014). Oreochromis niloticus has the highest concentration of all the heavy metals analysed. The metal concentrations in the samples were ranked in the following sequence: Oreochromis niloticus $>$ Clarias gariepinus $>$ Chrysichthys nigroditatus. Data from the previous literature showed that metal concentrations in fish fillets varied widely depending on the location and species (Fakankun et al., 2012) and the extent of contamination of the water body. The accumulation of heavy metals depends on the degree at which a particular species scavenges matters from the sediment and water (Koleleni and Haji, 2014, Ahmed et al., 2019). Ecological needs, feeding habit and food metabolism may also influence the degree of accumulation of toxicants and variations among species (Y1lmaz, 2003). The species that spend a longer time at the bottom of rivers and feed there are likely to concentrate metals than those that stay and feed at the surface (Tuzen, 2003). Taking $\mathrm{Pb}$ as an example, the key factors for its concentration and bioavailability in the aquatic environment are species, sampling sites, $\mathrm{pH}$, alkalinity and hardness and the degree of its absorption into the sediments or the organic matter content of the water (Mountouris et al., 2002; Gheorghe et al., 2017; Yahya et al., 2018). The points of release of effluents and wastewater and illegal dumping of wastes into water bodies are also key factors. Previous studies have documented both the natural and anthropogenic sources of heavy metals in the aquatic environment (Ahmed et al., 2019; Hossain et al., 2018; Babayemi et al., 2016; Varol and Sen, 2012; Bing et al., 2011). Specifically, the sources of $\mathrm{Pb}$ in the aquatic ecosystem may include effluents from industries (Rashed 2001). The anthropogenic sources of $\mathrm{Pb}$ include leaded gasoline, battery manufacturing, base metal mining, and its presence in water may result from industrial discharges and municipal wastewater (Babayemi et al., 2016). Indiscriminate use of phosphate fertilizer and the release of effluents from industries are the likely sources of $\mathrm{Cd}$; while textile industries may be the sources of $\mathrm{Cr}$ (Ahmed et al., 2019). The sources of $\mathrm{Cr}$ in the aquatic environment include the release of effluents from industries such as metal finishing, pharmaceutical industries, dyeing and printing industries, leather tanneries and textiles (Babayemi et al., 2016; Gabrielyan et al., 2018; Zhou et al., 2020). Therefore, controlling or monitoring the potential sources of heavy metals in the aquatic ecosystem could solve the problem of contamination of aquatic foods. Compared to the developed countries, there may be greater exposure to toxic metals in developing countries; and this may be as a result of inappropriate waste management or disposal (Babayemi et al., 2017) or widespread pollution (Babayemi et al., 2016). Ogun State has a larger percentage of industries in Nigeria. 
Heavy industrial activities may result in the release of toxic substances that may contaminate water, air and soil. Furthermore, Ogun River passes through several towns and villages before linking the lagoon in Lagos. Such water bodies are sources of water for direct drinking, cooking and other activities like irrigation and fishing in some rural areas (Babayemi, 2016), and can therefore constitute a human route of exposure.

Conclusion: The presence and levels of $\mathrm{Zn}, \mathrm{Pb}, \mathrm{Cr}, \mathrm{Cd}$ and $\mathrm{Fe}$ in fish from five different fishing locations along Ogun River were determined. Most of the results were lower than the FAO/WHO permissible limits except $\mathrm{Pb}$ and $\mathrm{Cr}$ which were higher. Some of the fish samples may pose health hazards to the consumers. There is the need for constant monitoring of pollutants in Ogun River.

\section{REFERENCES}

Adeniyi, AA; Yusuf, KA; Okedeyi, OO (2008). Assessment of the exposure of two fish species to metals pollution in the Ogun river catchments, Ketu, Lagos, Nigeria. Environ Monit Assess, 137(1-3):451-8.

Adewuyi, GO; Babayemi, JO; Olabanji, AA (2010). Assessment of toxicity of effluents discharged into waterways by some industries in Nigeria: a case study of Ibadan. Pac. j. sci., 11(2): 538-543.

Adeosun, FI; Alegbeleye, WO; Taiwo, IO; Oyekanmi, FB; Odebiyi, OC (2012) The effects of heavy metals concentration in some commercial fish in Ogun River, Opeji, Ogun State, Nigeria. In: 27th Annual Conference and Biennial General Meeting of the Fisheries Society of Nigeria (FISON), 25-30 Nov 2012 ,Bayelsa, Nigeria, pp. 268-271.

Agnew, UM; Slesinger, TL (2020). Zinc Toxicity. In: StatPearls [Internet]. Treasure Island (FL): StatPearls Publishing; 2020 Jan-. Available from: https://www.ncbi.nlm.nih.gov/books/NBK55454 8/

Ahmed, ASS; Sultana, S; Habib, A; Ullah, H; Musa, N; Hossain, MB; Md. Mahfujur, R; Md. Shafiqul, IS (2019) Bioaccumulation of heavy metals in some commercially important fishes from a tropical river estuary suggests higher potential health risk in children than adults. PLOS ONE 14(10):

Ayeloja, AA; George, FAO; Shorinmade, AY; Jimoh, WA; Afolabi, QO; Olawepo, KD (2014) Heavy metal concentration in selected fish species from eleyele reservoir Ibadan Oyo State South-Western Nigeria. Afr. J. Environ. Sci. Technol., 8 (7): 422427.

Austin, B (1999). The effects of pollution on fish health. Journal of Applied Microbiology Symposium Supplement, 85: 2348-2428

Andreji, J; Stránai, I; Massányi, P; Miroslav, V (2005). Concentration of Selected Metals in Fillet of Various Fish Species. J. Environ. Sci. Health, Vol 40 899-912.

Ayanda, IO; Ekhator, UI; Bello, OA (2019). Determination of selected heavy metal and analysis of proximate composition in some fish species from Ogun River, Southwestern Nigeria. Heliyon, 5 (10): e02512.

Azeez, RM; Babayemi, JO (2020). Levels of Heavy Metals in Commonly Consumed Vegetables Obtained from Some Markets in Ota, Nigeria. Anchor Univ. J. Sci. Tech. 1 (1): 96-101.

Babayemi, JO (2016). Overview of Levels of Organochlorine Pesticides in Surface Water and Food Items in Nigeria. J. Environ. Earth Sci. 6 (8): 77-86.

Babayemi, JO; Ogundiran, MB; Osibanjo, O (2016). Overview of environmental hazards and health effects of pollution in developing countries: a case of Nigeria. Environ. Quality Manage.26 (1): 5171.

Babayemi, JO; Ogundiran, MB; Osibanjo, O (2017a). Current levels and management of solid wastes in Nigeria. Environmental Quality Management 26 (3): 29-53.

Babayemi, JO; Olafimihan, OH; Nwude, DO (2017b). Assessment of Heavy Metals in Waterleaf from Various Sources in Ota, Nigeria. J. Appl. Sci. Environ. Manage. 21 (6): 1163-1168.

Bat, L; Arici, E; Sezgin, M; Şahin, F (2017). Heavy Metal Levels in Commercial Fishes Caught in the southern Black Sea coast. International Journal of Environment and Geoinformatics 4(2): 94-102

Bawuro, AA; Voegborlo, RB; Adimado, AA (2018). Bioaccumulation of Heavy Metals in Some Tissues of Fish in Lake Geriyo, Adamawa State, Nigeria. Journal of Environmental and Public Health, Article ID 1854892, 7 pages. https://doi.org/10.1155/2018/1854892 
Bing, H; Wu, Y; Sun, Z; Yao, S (2011). Historical trends of heavy metal contamination and their sources in lacustrine sediment from Xijiu Lake, Taihu Lake Catchment, China. Journal of Environmental Sciences. 23:1671-1678.

Bostanci, Z; Mack, RP; Enomoto, LM; Alam, S; Brown, A; Neumann, C; Soybel, DI; Kelleher, SL (2016). Marginal zinc intake reduces the protective effect of lactation on mammary gland carcinogenesis in a DMBA-induced tumor model in mice. Oncol. Rep., 35 (3): 1409-1416.

European Commission Regulation (EC). (2006). Setting maximum levels for certain contaminants in foodstuffs, No 1881.

Fakankun, OA; Babayemi, JO; Akosile, SO (2012). Evaluation of fish gills as potential target organ for accumulation of heavy metals. Afri. J. Animal and Biomedical Sci. 7(1): 15-18.

FAO 2003. Report of the FAO Working Group on the Assessment of Small Pelagic Fish off Northwest Africa.

Gabrielyan, AV; Shahnazaryan, GA; Minasyan, SH (2018). Distribution and Identification of Sources of Heavy Metals in the Voghji River Basin Impacted by Mining Activities (Armenia). Environmental Biogeochemistry of Elements and Emerging Contaminants, Volume 2018, Article ID 7172426, 9 pages. https://doi.org/10.1155/2018/7172426

Gheorghe, S; Stoica, C; Vasile, GG; Nita-Lazar, M; Stanescu E; Lucaciu, IE (2017). Metals Toxic Effects in Aquatic Ecosystems: Modulators of Water Quality, Water Quality, Hlanganani Tutu, IntechOpen, DOI: 10.5772/65744. Available from: https://www.intechopen.com/books/waterquality/metals-toxic-effects-in-aquaticecosystems-modulators-of-water-quality

Hossain, MB; Ahmed, ASS; Sarker, MSI (2018). Human health risks of $\mathrm{Hg}$, $\mathrm{As}, \mathrm{Mn}$, and $\mathrm{Cr}$ through consumption of fish, Ticto barb (Puntius ticto) from a tropical river, Bangladesh. Environ. Sci. Pollut. Res. 25:31727-31736.

Ibrahim, D; Ibrahim, AS; Paul, ED; Umar, M; Zannah, UAS (2018). Determination of Some Heavy Metal Content in Tilapia and Cat Fish Species in Lake Njuwa, Adamawa State, Nigeria. Journal of
Applied Sciences and Environmental Management, 22 (8): 1159-1165

Iji, OT; Adeogun, AO (2014). Industrial effluent induced chromosomal aberration in catfish from Ogun River, Lagos, Nigeria. Pakistan J. Biol. Sci. 17(5):675-681

Jacquin, L; Petitjean, Q; Côte, J; Laffaille, P; Jean, S (2020). Effects of Pollution on Fish Behavior, Personality, and Cognition: Some Research Perspectives. Front. Ecol. Evol., https://doi.org/10.3389/fevo.2020.00086

Jan, AT; Azam, M; Siddiqui, K; Ali, A; Choi, I; Haq, QMR (2015). Heavy Metals and Human Health: Mechanistic Insight into Toxicity and Counter Defense System of Antioxidants. Int J Mol Sci. 16(12): 29592-29630

Karadede H; Oymak, SA; Ünlü, E (2004). Heavy metals in mullet, Liza abu, and catfish, Silurus triostegus, from the Atatürk Dam Lake (Euphrates), Turkey. Environ. Int., Vol 30 183188

Kayode, AAA; Babayemi, JO; Abam, EO; Kayode, OT (2011). Occurrence and health implications of high concentrations of Cadmium and Arsenic in drinking water sources in selected towns of Ogun State, South West, Nigeria. J. Toxic. Environ. Health Sci. 3(15): 385-391.

Koleleni, YA; Haji, OO (2014). Determination of concentration of heavy metals in fish from sea port of zanzibar by Energy Dispersive X-ray Fluorescence (EDXRF) Tanz. J. Sci. 40: 79-89

Li, XF; Wang, PF; Feng, CL; Liu, DQ; Chen, JK; Wu, FC (2019). Acute Toxicity and Hazardous Concentrations of Zinc to Native Freshwater Organisms under Different $\mathrm{pH}$ Values in China. Bull. Environ. Contam. Toxicol. 103, 120-126

MacDonald, RS (2000). The Role of Zinc in Growth and Cell Proliferation. The J. Nutrition. 130 (5): 1500S-1508S,

Makanjuola, OM; Makanjuola, JO (2018). An assessment of heavy metals in the sediments of Ogun-Osun river basin, Oke-Odan, Yewa South local government area of Ogun State, Nigeria. $J$. Sci. Innov. Res. 7(4): 88-91 
Mason, LH; Harp, JP; Han, DY (2014). Pb Neurotoxicity: Neuropsychological Effects of Lead Toxicity. Biomed Res Int. 840547.

Mbeh, GM; Kamga, FT; Kengap, AK; Atem, WE; Mbeng, LO (2019). Quantification of heavy metals $(\mathrm{Cd}, \mathrm{Pb}, \mathrm{Fe}, \mathrm{Mg}, \mathrm{Cu}$, and $\mathrm{Zn}$ ) in seafood (fishes and crabs) and evaluation of health risks to consumers in Limbe, Cameroon. J. Mater. Environ. Sci. 10: 948-957

Morhit, ME; Belghity, D; Morhit, AE (2013). Metallic contamination in fillet of three fish species in the southern Atlantic coast the Laâyoune (Morocco), Larhyss Journal, 15: 21-34

Mountouris, A; Voutsas, E; Tassios, DP (2002). Bioconcentration of heavy metals in aquatic environments: The importance of bioavailability. Marine Pollution Bulletin 44(10):1136-41.

Muinde, VM; Nguu, EK; Ogoyi, DO; Shiundu, PM (2013). Effects of heavy metal pollution on omega-3 polyunsaturated fatty acids levels in tilapia fish from winam gulf Lake Victoria. The Open Environ. Eng. J. 6: 22-31

National Institutes of Health. (2020). Chromium: Dietary Supplement Fact Sheet. Retrieved from https://ods.od.nih.gov/factsheets/Chromium-

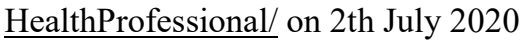

Nigam, A; Priya, S; Bajpai, P; Kumar, S (2014). Cytogenomics of hexavalent chromium $\left(\mathrm{Cr}^{6+}\right)$ exposed cells: A comprehensive review. Indian J Med Res. 139(3): 349-370. PMCID: PMC4069729, PMID: 24820829

Nwude, DO; Babayemi, JO; Owonifari, W (2012). Comparison of Phosphoric and Nitric Acid Digestion Procedures for the Determination of Metals in Cow Parts by Atomic Absorption Spectrophotometry. Inter. J. Appl. Res. Tech. 1(8): $100-106$.

Nwude, DO; Babayemi, JO; Abhulimen, IO (2011a). Metal quantification in cattle: a case of cattle at slaughter at Ota abattoir, Nigeria. J. Toxic. Environ. Health Sci. 3(9): 271-274.

Nwude, DO; Okoye, PAC; Babayemi, JO (2011b). Assessment of heavy metal concentrations in the liver of cattle at slaughter during three different seasons. Res. J. Environ. Sci. 5(3): 288-294
Nwude, DO; Okoye, PAC; Babayemi, JO (2010a). Assessment of accumulation of heavy metals in the kidney of cattle as a function of seasonal variation. African Journal of Animal and Biomedical Sciences, 5(3): 1-8.

Nwude, DO; Okoye, PAC; Babayemi, JO (2010b). Blood heavy metal levels in cows at slaughter at Awka abattoir, Nigeria. Inter. J. Dairy Sci. 5(4): 264-270

Nwude, DO; Okoye, PAC; Babayemi, JO (2010c). Heavy metal levels in animal fillet tissue: a case study of Nigeria raised cattle. Res. J. Appl. Sci. 5(2): $146-150$

Obot, OI; Isangedighi, AI; David, GS (2016). Heavy metals concentration in some commercial fishes in the lower Cross River estuary, Nigeria. Nig. J. Agric. Food Environ. 12(4):218-223.

Olatunde, KA; Arowolo, TA; Bada, BS; Taiwo, AM; Ojekunle, ZO (2014). Distribution and enrichment of metals in sediments of the Ogun River within Abeokuta, south-western Nigeria. Afr. J. Aquatic Sci. 39 (1): 17-22

Olusola JO; Festus AA (2015). Levels of Heavy Metal in Some Selected Fish Species Inhabiting Ondo State Coastal Waters, Nigeria. J Environ Anal Toxicol 5: 303.

Rashed M (2001). Monitoring of environmental heavy metals in fish from Nasser Lake. Environment International. 27:27-33.

Rostern, NT (2017). The Effects of Some Metals in Acidified Waters on Aquatic Organisms. Fish \& Ocean Opj. 4(4): 555645

Salam, MA; Paul, SC; Noor, SNBM; Siddiqua, SA; Aka, TD; Wahab, R; Aweng, ER (2019). Contamination profile of heavy metals in marine fish and shellfish. Global J. Environ. Sci. Manage., 5(2): 225-236.

Tüzen, M (2003). Determination of heavy metals in fish samples of the middle Black Sea (Turkey) by graphite furnace atomic absorption spectrometry. Food Chemistry, 80:119-123.

Unyimadu, JP; Osibanjo, O; Babayemi, JO (2019). Concentration and Distribution of Organochlorine Pesticides in Sediments of the Niger River, Nigeria. Journal of Health and Pollution: 9 (22): 190606. 
Unyimadu, JP; Osibanjo, O; Babayemi, JO (2018a). Levels of organochlorine pesticides in brackish water fish from Niger River, Nigeria. Journal of Environmental and Public Health. https://doi.org/10.1155/2018/2658306

Unyimadu, JP; Osibanjo, O; Babayemi, JO (2018b). Polychlorinated Biphenyls in Brackish Water Fish in the River Niger, Nigeria. Journal of Health and Pollution 8 (17): 31-42.

Unyimadu, JP; Osibanjo, O; Babayemi, JO (2018c). Selected Persistent Organic Pollutants (POPs) in water of River Niger: Occurrence and distribution. Environmental monitoring and assessment $\quad 190$ https://doi.org/10.1007/s10661-017-6378-4

Unyimadu, JP; Osibanjo, O; Babayemi, JO (2017). Polychlorinated biphenyls (PCBs) in River Niger, Nigeria: occurrence, distribution and composition profiles. Toxicology and Industrial Health 34 (1): 54-67.

Usero J; Morillo, J; Gracia, I (2003). Heavy metals in fish (Solea vulgaris, Anguilla anguilla and Liza aurata) from salt marshes on the southern Atlantic coast of Spain. Environment International, 29: 949-956.
Varol, M; Şen, B (2012). Assessment of nutrient and heavy metal contamination in surface water and sediments of the upper Tigris River, Turkey. Catena. 92:1-10.

WHO. (2019). Lead poisoning and health. https://www.who.int/news-room/factsheets/detail/lead-poisoning-andhealth\#: :text=Health\%20effects $\% 20$ of $\% 201$ ead \%20poisoning $\% 20$ on $\% 20$ children\&text $=\mathrm{At} \% 20$ high $\% 201$ evels $\% 20$ of $\% 20$ exposure,mental $\% 20$ re tardation $\% 20$ and $\% 20$ behavioural $\% 20$ disorders.

Yahya, AN; Mohamed, SK; Mohamed, AG (2018). Environmental Pollution by Heavy Metals in the Aquatic Ecosystems of Egypt. Open Acc J of Toxicol. 3(1): 555603

Yilmaz, AB (2003). Levels of heavy metals ( $\mathrm{Fe}, \mathrm{Cu}$, $\mathrm{Ni}, \mathrm{Cr}, \mathrm{Pb}$ and $\mathrm{Zn}$ ) in tissue of Mugil cephalus and Trachurus mediterraneus from Iskenderum Bay, Turkey. Environmental Research, 92: 277-281.

Zhou, Q; Yang, N; Li, Y; Ren, B; Ding, X; Bian, H; Yao, X (2020). Total concentrations and sources of heavy metal pollution in global river and lake water bodies from 1972 to 2017. Global Ecology and Conservation, 22: e00925 